\title{
Alterations in the oxidative metabolism of Rhipicephalus (Boophilus) microplus ticks in response to exposure to the insect growth regulator fluazuron
}

\author{
Alteraçóes no metabolismo oxidativo de carrapatos Rhipicephalus (Boophilus) microplus \\ em resposta à exposição ao regulador de crescimento fluazuron
}

Fabrício Nascimento Gaudêncio ${ }^{1 *}$; Vinícius Menezes Tunholi-Alves ${ }^{1}$; Mariana Gomes Lima ${ }^{1}$; Patrícia Silva Gôlo²; Isabele da Costa Angelo ${ }^{3}$; Rosane Nora Castro ${ }^{4}$; Adivaldo Henrique da Fonseca ${ }^{5}$; Fabio Barbour Scott ${ }^{6}$; Jairo Pinheiro ${ }^{1}$

\begin{abstract}
${ }^{1}$ Laboratório de Biofísica, Programa de Pós-graduação em Ciências Veterinárias, Departamento de Ciências Fisiológicas, Instituto de Ciências Biológicas e da Saúde, Universidade Federal Rural do Rio de Janeiro - UFRRJ, Seropédica, RJ, Brasil

${ }^{2}$ Laboratório de Controle Microbiano de Artrópodes de Importância Médico-Veterinária, Departamento de Parasitologia Animal, Instituto de Veterinária, Universidade Federal Rural do Rio de Janeiro - UFRRJ, Seropédica, RJ, Brasil

${ }^{3}$ Departamento de Epidemiologia e Saúde Pública, Instituto de Veterinária, Universidade Federal Rural do Rio de Janeiro - UFRRJ, Seropédica, RJ, Brasil

${ }^{4}$ Departamento de Química, Instituto de Ciências Exatas, Universidade Federal Rural do Rio de Janeiro - UFRRJ, Seropédica, RJ, Brasil

${ }^{5}$ Laboratório de Doenças Parasitárias, Departamento de Parasitologia Animal, Instituto de Veterinária, Universidade Federal Rural do Rio de Janeiro - UFRRJ, Seropédica, RJ, Brasil

${ }^{6}$ Laboratório de Quimioterapia Experimental em Parasitologia Veterinária, Departamento de Parasitologia Animal, Instituto de Veterinária, Universidade Federal Rural do Rio de Janeiro - UFRRJ, Seropédica, RJ, Brasil
\end{abstract}

Received November 17, 2015

Accepted December 9, 2015

\begin{abstract}
Aiming to characterize the potential off-target effects of fluazuron on ticks, biochemical analyses were conducted to evaluate changes in the carbohydrate metabolism of Rhipicephalus (Boophilus) microplus ticks after exposure to fluazuron. Hemolymph and fat body were collected from female ticks before and after (4, 8 and 15 days) exposure to fluazuron. Spectrophotometric analyses were done to quantify glucose concentration and lactate dehydrogenase (LDH) activity in the hemolymph and the concentration of glycogen in the tick's fat body. High Performance Liquid Chromatography (HPLC) was employed to determine the concentration of carboxylic acids in the hemolymph and to evaluate changes in intermediary metabolic processes requiring oxygen consumption. Increases in the levels of LDH activity and lactic acid concentration indicated that fluazuron enhanced fermentative metabolism in ticks. Exposure to fluazuron was also found to increase glucose concentrations in the hemolymph over time, although no significant differences were noted daily. In addition to expanding the body of knowledge about the mode of action of fluazuron, investigations into these mechanisms may also be useful in discovering new and as yet unexplored secondary effects.
\end{abstract}

Keywords: Benzoylphenylurea, chitin synthesis, organic acids.

\section{Resumo}

Com o objetivo de caracterizar os efeitos não-alvo da ação do fluazuron, foram realizados testes bioquímicos para analisar possíveis alteraçóes no metabolismo de carboidratos em carrapatos Rhipicephalus (Boophilus) microplus após sua exposição ao composto. Foram coletados hemolinfa e corpo gorduroso de fêmeas ingurgitadas antes e após (4, 8 e 15 dias) a exposição ao fluazuron. Análises espectrofotométricas foram usadas para quantificar a concentração de glicose e a atividade da lactato desidrogenase (LDH) na hemolinfa e concentração de glicogênio no corpo gorduroso. Cromatografia Líquida de Alta Eficiência (CLAE) foi usada para determinação das concentraçôes de ácidos carboxílicos na hemolinfa e avaliar possíveis alteraçóes em metabolismo intermediário em relação ao consumo de oxigênio. Aumento na atividade de

*Corresponding author: Fabrício Nascimento Gaudêncio. Programa de

Pós-graduação em Ciências Veterinárias, Departamento de Parasitologia Animal,

Instituto de Veterinária, Universidade Federal Rural do Rio de Janeiro - UFRRJ,

Rodovia BR 465, Km 7, Antiga estrada Rio-Sáo Paulo, CEP 23890-000,

Seropédica, RJ, Brasil. e-mail: fabriciogaudencio@hotmail.com 
LDH e concentração de ácido lático indicaram que o fluazuron pode regular o metabolismo fermentativo em carrapatos. A exposição ao fluazuron também aumentou a concentração de glicose na hemolinfa, apesar de não ter havido diferença significativa na comparação entre as médias no mesmo dia de avaliação. Além de aumentar o conhecimento sobre o modo de ação do fluazuron, investigaçóes sobre tais mecanismos também são úteis no descobrimento de novos efeitos secundários ainda náo explorados.

Palavras-chave: Benzofenilureia, síntese de quitina, ácidos orgânicos.

\section{Introduction}

Rhipicephalus (B.) microplus is a tick that preferably parasitizes cattle, causing significant losses to the livestock economy. One of the greatest challenges to cattle production in regions where $R$. (B.) microplus is endemic is the resistance to antiparasitic drugs (RECK et al., 2014). More than 75\% of the world's bovine population is parasitized by this tick, resulting in extremely widespread losses that impact successful beef production (CORDOVÉS, 1997).

During feeding, R.(B.) microplus can ingest up to one hundred times its own body weight in blood (SONENSHINE, 1991). Among other nutrients, the tick ingests carbohydrates (mainly glucose) to support its physiological requirements (NELSON \& COX, 2011; GUIZZO et al., 2012). Glucose is not only an excellent fuel for energy supply to the body but also represents a highly versatile precursor that can participate in a wide variety of metabolic processes, such as chitin biosynthesis (COHEN, 1987; NELSON \& COX, 2011; MERZENDORFER, 2011). Chitin is an amino-sugar polysaccharide that primarily forms extracellular structural elements in arthropod exoskeletons. Several chemical substances are known to inhibit chitin synthesis, e.g., fluazuron, a derivative of benzoylphenylurea, which regulates tick growth by inhibiting the incorporation of chitin into the tick's cuticle. This mechanism of action is especially well suited for controlling populations of $R$. (B.) microplus, which spends the entire parasitic part of its life cycle on the same animal, feeding preferentially on cattle (GRAF, 1993). The precise biochemical changes that chitin synthase inhibitors (such as acylurea insect growth regulators) produce in ticks have not yet been well described (COHEN, 2001). It is known that the inhibition of chitin metabolism may disrupt the production of hormones such that morphophysiological changes take place during arthropod development, resulting in the deposition of unviable eggs and the subsequent reduction in the emergence of new individuals (OLIVEIRA et al., 2013). However, the nutritional profile required by engorged females before the oviposition period and the inhibition of preliminary steps that lead to chitin formation are still largely unclear.

This study was conducted to evaluate possible changes in the metabolism of carbohydrates in $R$. (B.) microplus caused by exposure to fluazuron. The parameters that were evaluated to address these issues included the glycogen content in the fat body, glucose concentration, D and L-lactate dehydrogenase (EC 1.1.1.27; EC 1.1.1.28, respectively) (LDH) activities, and the concentrations of organic acids (oxalic, pyruvic and lactic acids) in the hemolymph of engorged females exposed to fluazuron. The aim was to better characterize the possible changes that occur to the oxidative metabolism of female ticks during the preoviposition period (after exposure to fluazuron). Variability in the concentrations of the above listed acids may reflect changes in the oxidative metabolism (Krebs's cycle).

\section{Materials and Methods}

\section{Ethics Committee}

This study was approved by the Bioethics Committee for Animal Experimentation of the Federal Rural University of Rio de Janeiro (CEUA-UFRRJ), under Protocol number: 023/2015.

\section{Tick collection protocol}

Each experimental group comprised 100 equal-weighted engorged female ticks that were separated into control and treatment groups. The mean weight of engorged females used in the experiment was 200-300 mg. Ticks were collected from the floors of six cattle stalls. The cattle used for this study were housed in separate stalls and were artificially infested with $1.0 \mathrm{~g}$ of tick larvae 21 days before each day of collection (day $-21,-17,-13,-6)$ (Figure 1), to obtain ticks of the same age and biological status. Using a topical route of administration (pour-on), the treated cattle received the dose

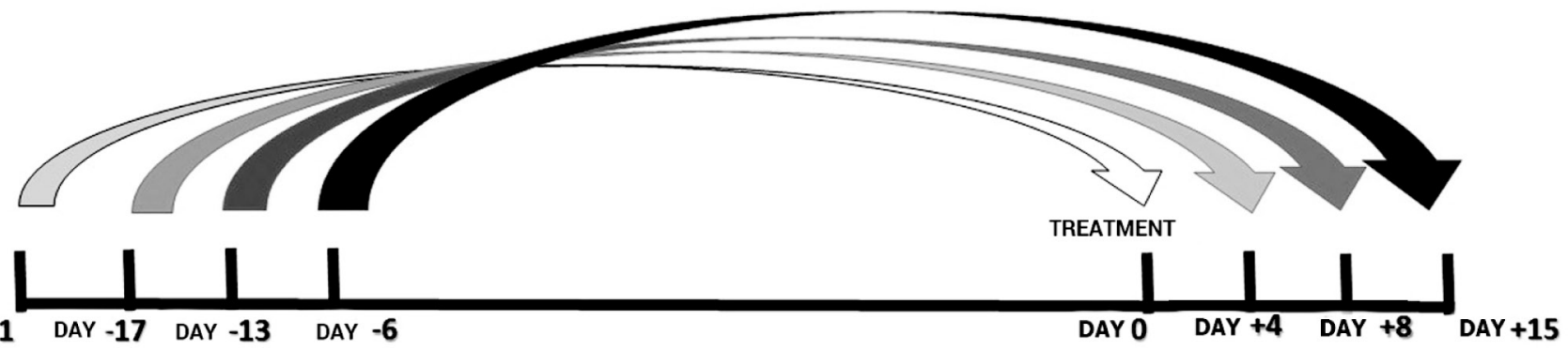

DAY -21 DAY -17

Figure 1. Schematic representation of the experimental design. Days of infestation with Rhipicephalus (B.) microplus larvae in cattle and days of collection of engorged adult females from stall floor 21 days later. Each arrow, all black, two grayscales, and all white, represents the day of infestation and its respective day of collection. 
recommended by the manufacturer, $2.5 \mathrm{mg}$ of fluazuron/kg live weight (Acatak ${ }^{\circledR}$ - Novartis Animal Health Inc., concentration: $25 \mathrm{~g} / \mathrm{L}$ of fluazuron). Experimental groups of ticks (control and exposed) were collected from stall floors on specific days, when ticks dropped off the cattle: the day prior to treatment (called 0) and at 4, 8 and 15 days after treatment. The collected ticks were washed in a $1 \%$ sodium hypochlorite solution for cuticle asepsis. The dissection was performed on the day of collection. The entire experiment was performed in triplicate.

\section{Hemolymph and fat body collection}

Hemolymph was collected from the dorsal region of the tick cuticle using a BD-Ultra-Fine ${ }^{\mathrm{TM}} 0.3 \mathrm{~mm}$ insulin needle, according to the protocol developed by Angelo et al. (2010). After applying gentle pressure on the body of the tick, hemolymph was collected using a $0.3 \mathrm{~mm}$ glass capillary tube attached to a flexible rubber tube. Hemolymph samples (maximum $500 \mu \mathrm{L}$ ) were pooled in a mixture of $30 \mu \mathrm{L}$ protease inhibitor cocktail (4-(2-aminoethyl) benzenesulfonyl fluoride (AEBSF), E-64, bestatin, leupeptin, apoprotinine; Sigma-Aldrich, São Paulo, SP, Brazil) and $82 \mu \mathrm{L}$ saline buffer (1.5 M NaCl; 50 mM EDTA; pH 7.2 and phenylthiourea). The hemolymph was then centrifuged at $5,040 \mathrm{~g}$ for 10 minutes to separate the hemocytes from the plasma portion to obtain cell-free hemolymph. The cell-free hemolymph containing protease inhibitor cocktail were stored at $-70{ }^{\circ} \mathrm{C}$.

The fat bodies of 100 engorged females from each group were dissected in phosphate buffer $(10 \mathrm{mM}, \mathrm{pH} 7.4)$ at $4{ }^{\circ} \mathrm{C}$ under a stereoscopic microscope. The fat bodies were removed from the ticks using tweezers and subsequently washed and homogenized with phosphate buffer $(10 \mathrm{mM}, \mathrm{pH} 7.4)$ at $4{ }^{\circ} \mathrm{C}$ using a Potter-Elvehjem homogenizer with a Teflon pestle, as described by Angelo et al. (2013).

\section{Determination of glycogen concentration}

The glycogen contents of the fatty bodies removed from the engorged female ticks were determined according to Pinheiro \& Gomes (1994). A $1 \mathrm{~mL}$ aliquot was collected from the neutralized sample and added to $1 \mathrm{~mL}$ of dinitrosalicylic acid (DNS). The absorbance of this mixture was read using a spectrophotometer at a wavelength of $500 \mathrm{~nm}$. The glycogen concentration was determined according to the Lambert-Beer law and expressed as mg of glucose/ $\mathrm{g}$ of tissue, fresh weight.

\section{Determination of glucose concentration and $\mathrm{LDH}$ activity}

To determine the glucose content and LDH activity of the hemolymph samples, the samples were diluted at a ratio of $1: 1$ in Milli-Q water. An automated A15 analyzer (Biosystems) was used for the analysis.

To determine the glucose concentration, $3 \mu \mathrm{L}$ of cell-free hemolymph was added to $300 \mu \mathrm{L}$ of color reagent (phosphate $100 \mathrm{mmol} / \mathrm{L}$, phenol $5 \mathrm{mmol} / \mathrm{L}$, glucose oxidase $10 \mathrm{U} / \mathrm{mL}$, peroxidase $1 \mathrm{U} / \mathrm{mL}$, 4-aminoantipyrine $0.4 \mathrm{mmol} / \mathrm{L}, \mathrm{pH} 7.5$ ), and the product resulting from the oxidation of 4-aminoantipyrine was spectrophotometrically measured at a maximum absorption of $510 \mathrm{~nm}$ at $37^{\circ} \mathrm{C}$ (TRINDER, 1969).

To determine the LDH activity, $6 \mu \mathrm{L}$ of hemolymph was added to $300 \mu \mathrm{L}$ of reagent (Tris $100 \mathrm{mmol} / \mathrm{L}$, pyruvate $2.75 \mathrm{mmol} / \mathrm{L}$, sodium chloride $222 \mathrm{mmol} / \mathrm{L}, \mathrm{pH} 7.2$, NADH $1.55 \mathrm{mmol} / \mathrm{L}$, sodium azide $9.5 \mathrm{~g} / \mathrm{L})$. Absorbance was measured at $340 \mathrm{~nm}$ at $37^{\circ} \mathrm{C}$ (SEQC, 1989; Scientific Commitee, 1982).

\section{Determination of organic acids}

Standards of oxalic, pyruvic and lactic acids were purchased from Sigma Aldrich (Steinheim, Germany) in the highest purity grade available. Acetonitrile, sodium dihydrogen phosphate and phosphoric acid were of analytical purity for chromatographic use. Ultrapure water was obtained from a Milli-Q water purification system (Millipore, Bedford, MA, USA). Stock standard solutions were dissolved in the mobile phase, and phosphate buffer was adjusted to $\mathrm{pH} 2.2$ with phosphoric acid and stored at $4{ }^{\circ} \mathrm{C}$.

The steps for determination of organic acids using HPLC were conducted in a Shimadzu LC-20AT system equipped with a photodiode array detector (PDA; SPD-M20A, Shimadzu, Japan) coupled to an LC Solution ChemStation data-processing station. Separations were carried out in a C18 reverse phase column $\left(150 \times 4.5 \mathrm{~mm}\right.$ I.D., $5 \mu \mathrm{m}$, Allure ${ }^{\circledR}$ Organic Acids, Restek) under isocratic conditions. The mobile phase consisted of $1 \%$ acetonitrile in $20 \mathrm{~mol} \mathrm{~L}^{-1} \mathrm{NaH}_{2} \mathrm{PO}_{4}$ aqueous solution, adjusted to $\mathrm{pH} 2.2$ using $\mathrm{H}_{3} \mathrm{PO}_{4}$. The temperature was set at $36{ }^{\circ} \mathrm{C}$, and the flow rate was $0.8 \mathrm{~mL} / \mathrm{min}$. The chromatograms were monitored at $210 \mathrm{~nm}$, and the injection volume was $20 \mu \mathrm{L}$. To identify organic acids in the samples, the UV spectra and retention times of sample solutions were compared to those obtained from pure standard solutions. Quantification was performed on the basis of linear calibration plots of peak area against concentration. Calibration lines were constructed based on five concentration levels of standard solutions. The calibration graphs for oxalic, pyruvic and lactic acids were linear $(r=0.99)$ in all cases. All the experiments were performed in triplicate. The hemolymph containing the protease inhibitor cocktail was vortexed and centrifuged for $10 \mathrm{~min}$ at $2520 \mathrm{~g}$. The supernatant was separated, and undissolved particles were removed by filtration through $45 \mu \mathrm{m}$ membrane filters. Aliquots of $20 \mu \mathrm{L}$ were used for the chromatographic analysis (TUNHOLI-ALVES et al., 2014).

\section{Statistical analyses}

The results of glucose concentration, glycogen concentration and LDH activity were expressed as the mean \pm standard error. The Kruskal-Wallis test was followed by Dunn test to compare the means (InStat, GraphPad v.4.00 and v.3.02, Prism, Inc.).

The results of organic acids concentration were expressed as mean \pm standard deviation and the ANOVA test was followed by Tukey test to compare the means (InStat, GraphPad v.4.00 and v.3.02, Prism, Inc.). 


\section{Results}

The glycogen concentrations in the exposed group on day 15 (12.06 $\pm 0.04 \mathrm{mg}$ of glucose/ $\mathrm{g}$ of tissue, wet weight) were significantly higher than those of the exposed group at time zero $(0.21 \pm 0.01 \mathrm{mg}$ of glucose/ $\mathrm{g}$ of tissue, wet weight) and 8 days after treatment of the cattle $(0.243 \pm 0.02 \mathrm{mg}$ of glucose/ $\mathrm{g}$ of tissue, wet weight), representing $+5,642.86 \%$ and $+4,862.96 \%$, respectively. In spite of these highest glycogen concentrations, there were no significant differences $(p>0.05)$ when they were statistically compared to the values obtained to control groups (Figure $2 \mathrm{~b}$ ).

The glucose concentration in the hemolymph of ticks at the 8th day after exposure $(107.3 \pm 0.6 \mathrm{mg} / \mathrm{dL})$ showed no difference $(p>0.05)$ in relation to the value obtained in the control (unexposed) group at the same day of analysis. However, it differed significantly $(p<0.05)$ from that of the control group on day $15(20.6 \pm 1.3 \mathrm{mg} / \mathrm{dL})$. The glucose content in the hemolymph of fluazuron-exposed ticks was being gradually increased throughout the period of analysis when compared to the value obtained to the respective control group turning higher than the unexposed group from the 8th day onward (Figure 2a). This finding suggests a relationship between the reduced mobilization of glucose during chitin biosynthesis and glycogen accumulation in the fat body.

The LDH activity measured in ticks exposed to fluazuron increased continuously until the last day of evaluation. The results indicated that this activity differed significantly $(p<0.05)$ from the values obtained on day 4 from unexposed ticks $(106.66 \pm 2.90 \mathrm{U} / \mathrm{L})$ and on day 15 from exposed ticks $(270.66 \pm 17.14 \mathrm{U} / \mathrm{L})$. This increase corresponded to a variation of $153.75 \%$ on day 15 .

Significant alterations $(p<0.05)$ in the concentrations of organic acids were also observed. The concentration of oxalic acid in the exposed group gradually increased over time. From day 4 to day 15 post-exposure, the oxalic acid concentration in the fluazuron-exposed group was consistently higher than in the unexposed group during that period (Figure $3 \mathrm{~d}$ ) and peaked on day 15 after exposure to fluazuron $(0.092 \pm 0.001 \mathrm{mM})$, differing significantly $(p<0.05)$ from the means of the unexposed group on all the days analyzed in both the control and exposed groups.

The concentration of lactic acid in the treated group showed a similar trend, with significantly $(p<0.05)$ higher values observed on day $15(3.883 \pm 0.056 \mathrm{mM})$ relative to all the other groups, control and exposed, on the days of evaluation. At some points, the control group was undetectable by the HPLC analysis, due to the very low concentration, except on day 8 after exposure. However, note that the lactic acid concentration increased gradually over time, reaching its peak on day 15 (Figure $3 \mathrm{~b}$ ).

Despite the differences found in the levels of pyruvic acid measured in fluazuron-exposed and control ticks during the experiment, no trends were observed when graphing these values (Figure 3c). The concentrations of pyruvic acid in the fluazuron-exposed group were significantly $(p<0.05)$ higher than in the control group from time zero to day 8 post-exposure. However, the values observed on day 15 in the control $(0.05 \pm 0.001 \mathrm{mM})$ and exposed groups $(0.045 \pm 0.001 \mathrm{mM})$ did not differ statistically $(p>0.05)$.
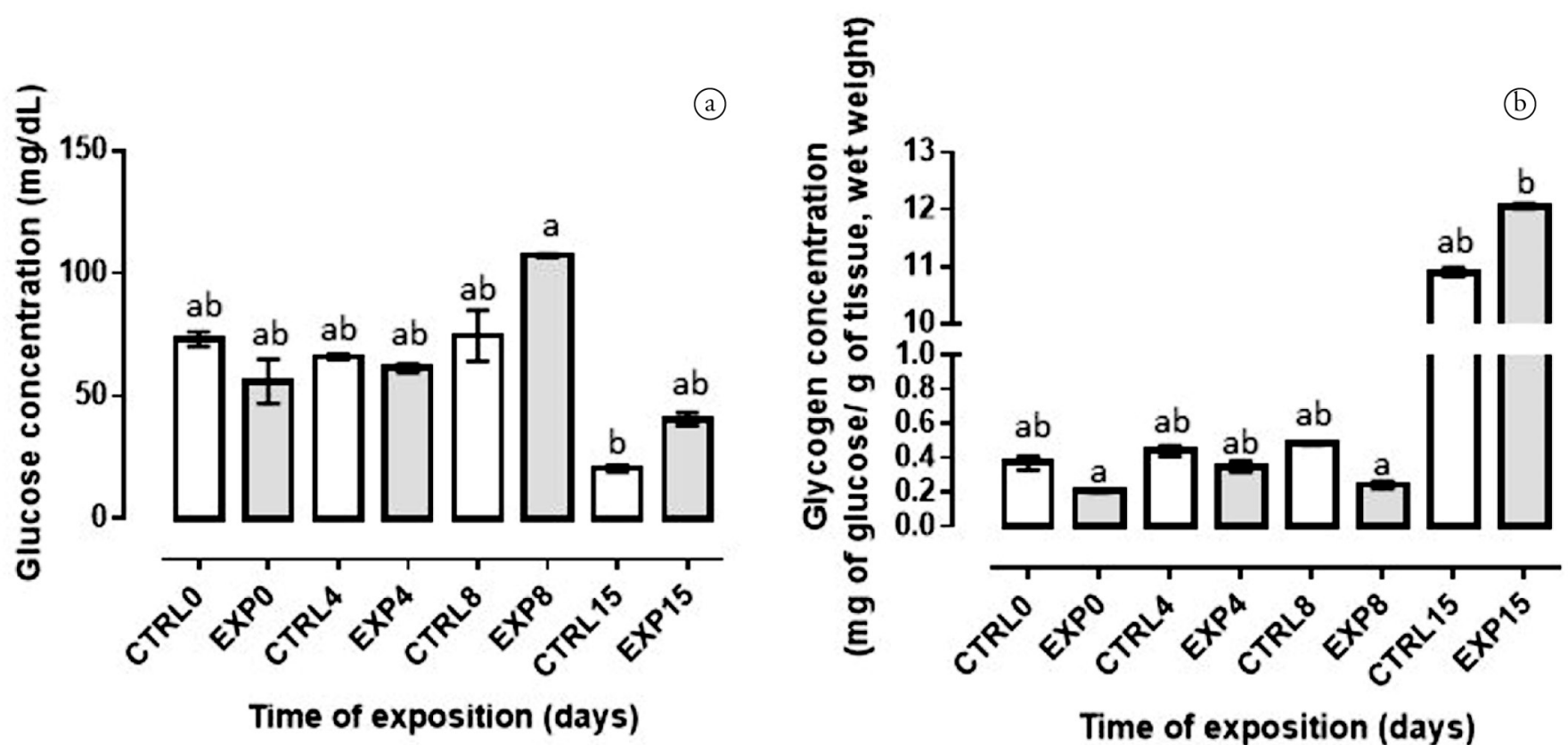

Figure 2. Changes in the carbohydrate metabolism of engorged female Rhipicephalus (B.) microplus ticks collected from cattle stall floors on different days following exposure to fluazuron. CTRL: control group. EXP: fluazuron-exposed group. The following number after CTRL and EXP represents the day before (0) and after (4, 8 and 15) fluazuron-exposure. (a) Glucose concentration (mg/dL); (b) Glycogen concentration in the fat body ( $\mathrm{mg}$ of glucose/g of tissue, wet weight). Mean values appended by different letters were found to differ significantly between groups on each day of the experiment $(\mathrm{P}<0.05)$. Mean \pm standard error. 

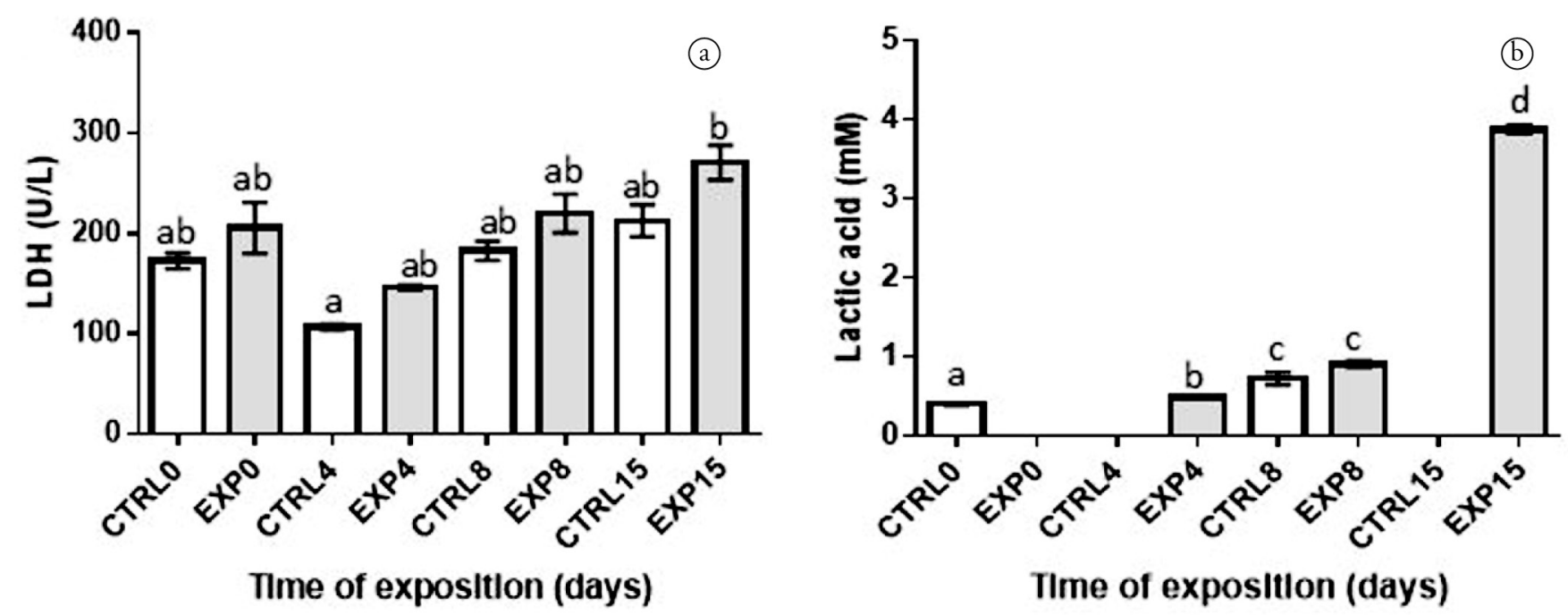

(c)

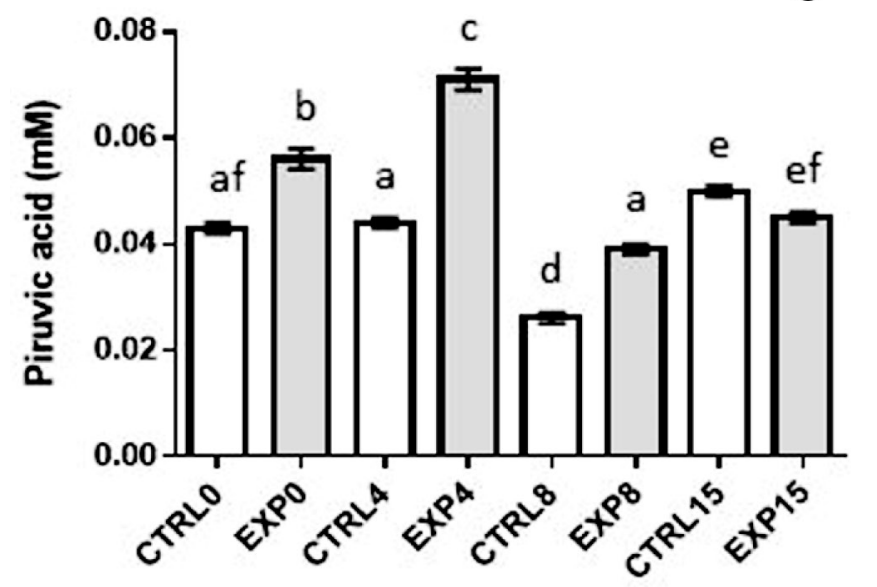

Time of exposition (days)

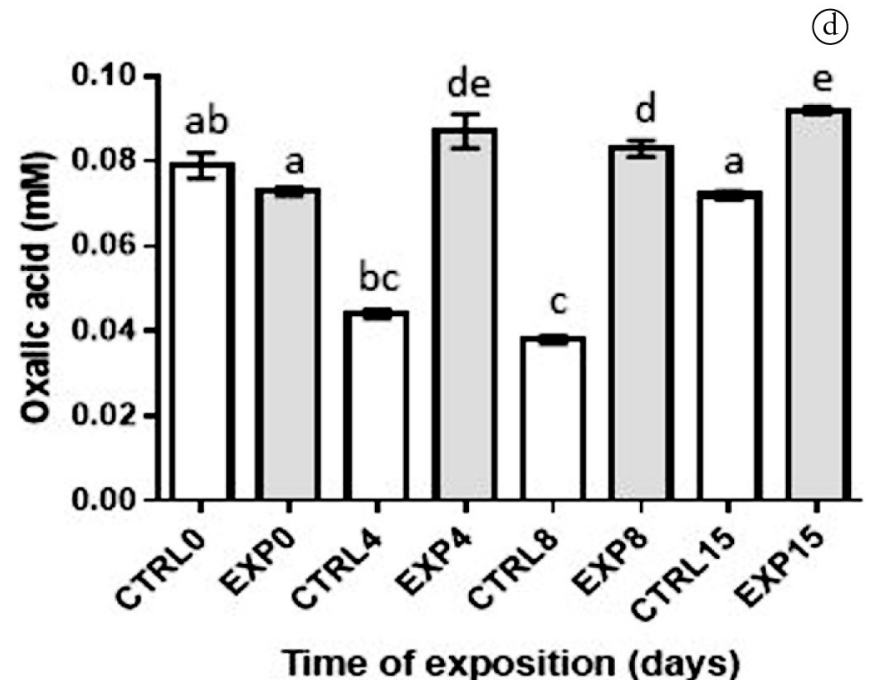

Figure 3. Changes in the enzyme lactate dehydrogenase (LDH) activity and organic acids contents of engorged female Rhipicephalus (B.) microplus ticks collected from cattle stall floors on different days following exposure to fluazuron. CTRL: control group. EXP: fluazuron-exposed group. The following number after CTRL and EXP represents the day before ( 0 ) and after ( 4,8 and 15) fluazuron-exposure. (a) LDH activity (U/L); (b) Lactic acid concentration (mM); (c) Pyruvic acid concentration (mM); and (d) Oxalic acid concentration (mM). Mean values appended by different letters were found to differ significantly between groups on each day of the experiment $(\mathrm{P}<0.05)$. Mean \pm standard error for $(\mathrm{a})$ and mean \pm standard deviation for (b), (c) and (d).

\section{Discussion}

Glucose is the most abundant carbohydrate contained in the hemolymph of adult ticks (LEVENBOOK et al., 1980) and the embryonic development of $R$. (B.) microplus depends upon maternal glucose to complete the maturation of eggs (MORAES et al., 2007; GUIZZO et al., 2012). To support this and various others biosynthetic processes, the demand for glucose rises drastically during the $24 \mathrm{~h}$ period following parasitic feeding, as well as in the preoviposition period lowering glucose concentration levels in the hemolymph (TATCHELL \& SCHUNTNER, 1972). Previous studies that have attempted to elucidate the exact mechanism behind the action of benzoylphenylureas gave rise to speculations about their involvement in other pathways. They may affect not only the chitin biosynthesis events (COHEN, 2001), but also others processes, as the inhibition of the glucose conversion into fructose-6-phosphate (PALLI \& RETNAKARAN, 1999), an important step known in glycolysis too (NELSON \& COX, 2011). However, whether these compounds produced potential consequences to other metabolic pathways involving glucose in ticks (and potential mechanisms of action governing them) had not yet been confirmed. Cohen (2001) stated that fluazuron inhibits glucose phosphorylation process. In accordance to his results, our findings suggested that an imbalance in glucose homeostasis occurs due to the previous inhibition of chitin synthase caused by fluazuron. This can be demonstrated by the increased glucose concentrations in the hemolymph of engorged ticks, which reflects an increase in the glycogen store of the fat body. This effect was 
more clearly illustrated by the increasing length of time that the female tick fed on cattle blood containing the active compound fluazuron.

In addition to performing several metabolic functions, the parietal fat body of the tick stores food reserves and metabolizes hormones and other essential messenger molecules. It also tends to accumulate large stores of lipid droplets, glycogen and protein (SONENSHINE, 1991). On day 15 of treatment, glycogen concentrations within the fat body of fluazuron-exposed ticks were significantly higher than those measured in the exposed group at time zero and on day 8 . The inhibition of chitin biosynthesis caused by fluazuron may suppress the utilization of glucose in other biosynthetic and catalytic events consequently enhancing the store of glucose as glycogen granules in fat body. The cells of the fat body normally contain few glycogen granules that are only present during nymph feeding and the ecdysial phases (SONENSHINE, 1991), which suggests that the accumulation of glycogen is due to the reduction of glucose degradation rate. Once glucose catabolic pathways have been suppressed, the acceleration of glycogenolysis is no longer required, allowing the opposite reaction of glycogenesis to be enhanced.

To better understand how exposure to fluazuron affects the oxidative carbohydrate metabolism of $R$.(B.) microplus, the LDH activity in hemolymph and hemolymph concentrations of certain organic acids, including oxalic, pyruvic and lactic acids were measured. Interestingly, the gradual increase in LDH activity, although without significant difference between the evaluated days, mirrored the increasing concentration of lactic acid in the hemolymph. The establishment of this metabolic condition suggests the ability of $R$. (B.) microplus to activate alternative metabolic pathways to obtain energy, highlighting the importance of $\mathrm{LDH}$ involvement in this process. This metabolic scenario was also accompanied by an accumulation of oxalic acid in the hemolymph of the treated group, indicating a slowing down of the oxidation-reduction reactions that make up the Krebs cycle. This fact is clearly evident when the overall pattern of the citric acid cycle and the real role of oxalic acid in the oxidation of acetylated molecules are considered. Thus, it has been suggested that aerobic energy metabolism is impaired under such conditions and that the activation of anaerobic pathways is required to maintain the redox balance (NELSON \& COX, 2011). However, the pyruvic acid concentration did not decrease in response to the activation of the fermentative pathways. Instead, this phenomenon was attributed to the activation of metabolic ways that increase the concentration of pyruvic acid through the action of transaminases on $\alpha$-amino acids, which supply ketoacids to the Krebs cycle through transamination reactions (NELSON \& COX, 2011).

This paper offers the first reported changes in the oxidative metabolism that occur in $R$.(B.) microplus ticks exposed to fluazuron. These changes included alterations in carbohydrate metabolism and changes in the concentrations of organic acids in the tick, suggesting that multiple modes of action culminate in egg unviability, leading to low egg production and hatching rates. It is possible that the high mortality rates observed in the larval and nymph stages of susceptible strains are also the result of inefficient control of these effects in intermediary metabolism, due to disruption of the chitin metabolism. An additional effect may be interference in other metabolic pathways.

The results of the present study validate the hypothesis of loss of glycemic homeostasis in the hemolymph of engorged female ticks, suggesting that the tick's survival depends on the activation of compensatory physiological mechanisms. The increase in $\mathrm{LDH}$ activity, in addition to the augmented levels of lactic acid in the hemolymph, indicate that fermentative anaerobic metabolism is a metabolic strategy this arthropod employs in response to conditions of physiological stress. The data discovered in this study confirm that the inhibition of chitin biosynthesis interferes with additional targets through unknown pathways and mechanisms, thus providing insights into the effectiveness of the chemical. Such insights may facilitate the identification of new parasite drug targets as well as strategies for better tick control.

\section{Acknowledgements}

This study was supported in part by the Brazilian research funding agencies Fundação Carlos Chagas Filho de Amparo à Pesquisa do Estado do Rio de Janeiro (FAPERJ), under Grant No. E-26/102.304/2013 and Conselho Nacional para o Desenvolvimento Científico e Tecnológico (CNPq), under Grant No. 447211/2014-5.

\section{References}

Angelo IC, Gôlo PS, Camargo MG, Kluck GEG, Folly E, Bittencourt VREP. Haemolymph protein and lipid profile of Rhipicephalus (Boophilus) microplus infected by fungi. Transbound Emerg Dis 2010; 57(1-2): 79-83. http://dx.doi.org/10.1111/j.1865-1682.2010.01119.x. PMid:20537114.

Angelo IC, Gôlo PS, Perinotto WMS, Camargo MG, Quinelato S, Sá FA, et al. Neutral lipid composition changes in the fat bodies of engorged females Rhipicephalus microplus ticks in response to fungal infections. Parasitol Res 2013; 112(2): 501-509. http://dx.doi.org/10.1007/s00436012-3159-4. PMid:23138474.

Cohen E. Chitin biochemistry: synthesis and inhibition. Annu Rev Entomol 1987; 32(1): 71-93. http://dx.doi.org/10.1146/annurev. en.32.010187.000443.

Cohen E. Chitin synthesis and inhibition: a revisit. Pest Manag Sci 2001; 57(10): 946-950. http://dx.doi.org/10.1002/ps.363. PMid:11695188.

Cordovés CO. Carrapato: controle ou erradicaçâo. Guaíba: Agropecuária; 1997.

Graf JF. The role of insect growth regulators in arthropod control. Parasitol Today 1993; 9(12): 471-474. http://dx.doi.org/10.1016/01694758(93)90106-P. PMid:15463697.

Guizzo MG, Abreu L, Masuda A, Logullo C, Vaz IS Jr. Metabolismo de biomoléculas na embriogênese do carrapato Rhipicephalus (Boophilus) microplus. Acta Sci Vet 2012; 40(1): 1-12.

Levenbook L, Boctor FN, Fales HM. Biochemical studies of tick embryogenesis: free sugars in adult haemolymph and during embryogenesis of Dermacentor andersoni. J Insect Physiol 1980; 26(6): 381-383. http:// dx.doi.org/10.1016/0022-1910(80)90008-6. 
Merzendorfer $\mathrm{H}$. The cellular basis of chitin synthesis in fungi and insects: common principles and differences. Eur J Cell Biol 2011; 90(9): 759769. http://dx.doi.org/10.1016/j.ejcb.2011.04.014. PMid:21700357.

Moraes J, Galina A, Alvarenga PH, Rezende GL, Masuda A, Vaz IS Jr, et al. Glucose metabolism during embryogenesis of the hard tick Boophilus microplus. Comp Biochem Physiol A Mol Integr Physiol 2007; 146(4): 528 533. http://dx.doi.org/10.1016/j.cbpa.2006.05.009. PMid:16904922.

Nelson DL, Cox MM. Princípios de bioquímica de Lehninger. Porto Alegre: Artmed; 2011.

Oliveira PR, Calligaris IB, Roma GC, Bechara GH, Camargo-Mathias MI. Fluazuron-induced morphophysiological changes in the cuticle formation and midgut of Rhipicephalus sanguineus Latreille, 1806 (Acari: Ixodidae) nymphs. Parasitol Res 2013; 112(1): 45-58. http://dx.doi.org/10.1007/ s00436-012-3103-7. PMid:22992894.

Palli SR, Retnakaran A. Molecular and biochemical aspects of chitin synthesis inhibition. In: Jolles P, Muzzarelli RAA. Chitin and chitinases. Basel: Birkhauser Verlag; 1999. p. 85-98.. http://dx.doi.org/10.1007/9783-0348-8757-1_6.

Pinheiro J, Gomes EM. A method for glycogen determination in mollusks. Braz Arch Biol Technol 1994; 37: 569-576.

Reck J, Klafke GM, Webster A, Dall'Agnol B, Scheffer R, Souza UA, et al. First Report of fluazuron resistance in Rhipicephalus microplus: a field tick population resistant to six classes of acaricides. Vet Parasitol 2014;
201(1-2): 128-136. http://dx.doi.org/10.1016/j.vetpar.2014.01.012. PMid:24560364.

Scientific Commitee. Recommandations pour la mesure de la concentration catalytique de la lactate deshidrogenase dans le serum humain a $30{ }^{\circ} \mathrm{C}$. Ann Biol Clin 1982; 40: 87-164.

Sociedad Española de Química Clínica - SEQC. Comité Científico, Comisión de Enzimas. Método recomendado para La determinación en rutina de La concentración catalítica de lactato deshidrogenasa em suero sanguíneo humano. Quim Clin 1989; 8: 57-61.

Sonenshine DE. The biology of ticks. Oxford: Oxford University Press; 1991.

Tatchell RJ, Schuntner CA. Glucose metabolism in the cattle tick Boophilus microplus. J Insect Physiol 1972; 18(2): 283-288. http://dx.doi. org/10.1016/0022-1910(72)90128-X.

Trinder P. Determination of glucose in blood using glucose oxidase with an alternative oxygen acceptor. Ann Clin Biochem 1969; 6(1): 24-27. http://dx.doi.org/10.1177/000456326900600108.

Tunholi-Alves VM, Tunholi VM, Castro RN, Sant'Ana LDO, SantosAmaral L, Oliveira APM, et al. Activation of anaerobic metabolism in Biomphalaria glabrata (Mollusca: Gastropoda) experimentally infected by Angiostrongylus cantonensis (Nematoda, Metastrongylidae) by highperformance liquid chromatography. Parasitol Int 2014; 63(1): 64-68. http://dx.doi.org/10.1016/j.parint.2013.09.004. PMid:24042059. 